\title{
ГЕРОЇКА НАЦІОНАЛЬНОГО ДЕРЖАВОТВОРЕННЯ 1918-1919 рр. У ФОРМУВАННІ ІДЕЙНОГО ПІДГРУНТЯ ЗБРОЙНОГО ЧИНУ ОУН (б) У ГАЛИЧИНІ (друга половина 1943 р. - початок 1944 р.)
}

\author{
Ігор ДРОГОБИЦЬКИЙ \\ Івано-Франківський обласний інститут післядипломної освіти, \\ кафедра теорії та методики навчання, \\ пл. А. Мічкевича 3, 76000, м. Івано-Франківськ, Україна \\ e-mail:drogobutsky@ukr.net \\ DOI: 10.15330/gal.32.186-192 \\ ORCID: 0000-0001-8718-9544
}

\section{Роман РОМАНІB}

Івано-Франківський національний технічний університет нафти ігазу, кафедра військової підготовки, вул. Коновальия 72 а, 76018, м. Івано-Франківськ, Украӥна e-mail:1977lem1977@gmail.com DOI: 10.15330/gal.32.186-192 ORCID: 0000-0003-1392-6665

У матеріалах статті йдеться про тяглість традииї національної державотворчої боротьби у 20-40-х рр. ХХ ст. Представлено окремі аспекти використання етосу визвольних змагань українських збройних формацій 1917-1921 р. Організацією украӥнських націоналістів (бандерівців) у Галичині в період Другої світової війни. Окреслено особливості вжитку керівництвом націоналістичного крила вітчизняного начіонально-визвольного руху Опору героїки військового чину національних мілітарних формацій періоду Західно-Украӥнської Народної Республіки та Украӥнської Народної Республіки для створення ідеологічного підгрунтя процесу розгортання власних збройних сил - Украйнської Народної Самооборони та Української Повстанської Армії.

Простежено паралелі у означенні кінцевої мети збройної боротьби нації. Вказано також на відмінності у концепції та тактичних засобах осягнення наџіонального суверенітету. Відзначено, щзо дослідження представленої теми уможливлюють глибше сприйняття загалом вітчизняного сочіуму процесу відстоювання національних прав, а, зокрема, державної незалежності.

У ході висвітлення теми зроблено акцент на використанні матеріалів підпілля та джерел мемуаристичного характеру.

Ключові слова: державність, національний суверенітет, рух Опору, націоналістичне підпілля, Організація Українських Націоналістів, Украӥнська Повстанська Армія.

Визначальні аспекти внеску Організації українських націоналістів (бандерівців) (далі - ОУН (б)) у еволюцію українського національного державотворення у часі нацистсько-радянської війни (1941-1945 рр.) досить розгорнуто представлено в існуючій історичній літературі ${ }^{1}$. Відзначимо, що дослідження означених процесів $є$ злободенними в умовах сучасного військового протистояння із зовнішнім агресором та необхідності системної роботи спрямованої на внутрішню консолідацію вітчизняного соціуму.

\footnotetext{
${ }^{1}$ Історія українського війська. 1917-1995 / упор.: Я. Дашкевич. Львів : Світ, 1996. 840 с. ; Киричук Ю. Український національний рух 40-50-х років XX століття : ідеологія і практика. Львів : Львівський нац. ун-т ім. І. Франка. Добра справа. 2003. 463 с. ; Збірник матеріалів I Міжнар. наук. конф. "Національновизвольна боротьба 20-50-х років ХХ ст. в Украӥні” Київ ; Львів, 1993. 293 с. ; Киричук Ю. Нариси $з$ історії українського національно-визвольного руху 40-50-х років XX ст. Львів : Львівський нац. ун-т ім. Івана Франка, 2000. 305 с. тощо.
} 
3 метою системного та цілісного представлення історії національних державницьких змагань у XX ст. необхідним видається аналіз практики використання представниками державницьких сил періоду Другої світової війни, а зокрема ОУН (б), тодішньої історичної пам'яті про національну революцію 1917-1921 рр. У цьому контексті доречним є окреслення як елементів ідеологічної програми націоналістів, так і форм привнесення епосу визвольної боротьби у процес створення оунівцями власних військових структур у регіоні. Важливо також окреслити характерні відмінності у державотворчих заходах загалом та концепціях, що стосувалися розбудови національної військової сфери, зокрема між представниками “старшого" та "молодшого” покоління політичних діячів краю. Такий аналіз уможливлює констатування еволюції процесу національного державотворення, що у свою чергу, є одним із аргументів супроти тверджень про домінування “анархічних", “бездержавницьких” тенденцій у життєдіяльності українського етносу.

Окремі дослідники не без підстав стверджують, що своєю активністю, зокрема i на державотворчій ниві, молодша генерація, яка ідентифікувала себе із ОУН (б), кидала виклик усталеним формам політичної діяльності. Із своєю “революційною працею” іiі адепти намагалися привнести у соціум нові форми, методи та засоби боротьби за інтереси національної спільноти, визначальним із яких була Українська самостійна соборна держава (далі - УССД).

Водночас, слід підкреслити, що остаточні цілі соціально-політичної активності не піддавалися переосмисленню. У розпалі Другої світової війни делегати III-го Надзвичайного Великого Збору ОУН (б) (21-25 травня 1943 р.) у “Постановах" наголошують на тому, що “ОУН проти того, щоб один народ, здійснюючи імперіалістичні цілі, “визволяв”, “брав під опіку” ... інші народи, бо за цими лукавими словами криється огидний зміст - поневолення, насильство, грабунок. ... Тому ОУН бореться ... поки не здобуде Української Самостійної Соборної Держави",2. Отож чітко простежується спільність в означенні кінцевої мети національно-визвольних змагань між учасниками Національного Здвигу 1917-1921рp. та представниками націоналістичного крила національного руху Опору середини 40-х рр. ХХ ст.

Схожість позиції простежується також в означенні визначальної сили, яка б мала реалізовувати стратегію розвитку нації. У цьому контексті творці ідеологічної платформи ОУН (б) зазначали: “Бистре око молодого українського політика не прогавить ані одного моменту, і в кожний сприятливий час кидає світові ... єдину правду: на Україні має право творити Українську Державу лише український народ! ... За боротьбою українського народу традиція оспівана ... піснями кулеметів-гранат Визвольних Змагань 1918-1920 рр."3.

Водночас, підкреслюючи власне бачення шляхів реалізації права нації на державний суверенітет, керівництво як ОУН загалом, так і ОУН (б) зокрема, виступали із критикою тих способів та форм, які практикувалися у державотворчому процесі доби національно-визвольних змагань 1917-1921 рр.

\footnotetext{
${ }^{2}$ Постанови III Надзвичайного Великого Збору Організації Українських Націоналістів, що відбувся в днях 21-25 серпня 1943 р. Ідея $і$ чин. 1943 (Рік II). № 5 ; Літопис УПА. Основна серія / за ред.: Ю. Маївського, С. Штендери. Торонто : Літопис УПА, 1995. Т. 24 : Ідея і чин: Орган Проводу ОУН, 1942-1946. Передрук підпільного журналу. С. 231.

3 "Ратай". За державу. Стрілеиькі вісті. Орган ВШВО ІІ. 1944 (Рік I). Ч. 19. 30 червня 1944 р. ; Літопис УПА. Нова серія / редкол.: / НАН України, Ін-т української археографії та джерелознавства ім. М. С. Грушевського НАН України, Державний комітет архівів України, ЦДАГО України, ГДА СБУ. Київ ; Торонто : Літопис УПА, 2009. Т. 13 : Воєнна Округа УПА “Буг” 1943-1952. Документи і матеріали. Кн. II. C. 455 .
} 
Проте окремі аспекти боротьби національних збройних формувань згаданого періоду, а зокрема Українських Січових Стрільців, Української Галицької Армії (далі УГА), Дієвої армії Української Народної Республіки (далі - ДА УНР) тощо, широко використовувалися в ідеологічній та пропагандистській сфері діяльності націоналістів. Ідеологами ОУН (б) констатувалося: “Сьогодні ... тільки ОУН, як політичний провід ... як мілітарна сила, при всецілій підтримці участі цілого українського народу зможе ... зламати всі перешкоди і створити та кріпити раз на все те, за що ... кервавилась УГА (Українська Галицька Армія - авт.), Армія Петлюри, за що бореться довгі роки ОУН і що проголосила 30 червня 1941 р. - Українську Самостійну Соборну Державу”4. Підкреслюючи, таким чином, тяглість процесу державотворення, оунівці наголошували на значенні єдиного керівного центру в представленні презентованої ними політичної сили. Крім цього, на відміну від широкого кола представників вітчизняного політикуму доби 1917-1921 рр., лідерами ОУН (б) ніколи не ставився під сумнів збройний характер процесу осягнення УССД. Через це питання створення збройних сил набувало в концепції державотворення націоналістів першочергової ваги. Саме тому серед юнацтва ОУН (б) пропагувалася теза про те, що “тільки зброя дасть нам волю", .

Крім цього “покликання” представників молодої генерації вітчизняного націоналістичного руху на окремі складові досвіду старшого покоління борців за державний суверенітет обумовлювалися необхідністю постання та зміцнення ознак життєздатного національного організму. Михайло Дяченко окреслював їх як “чинники, що творять власні сили народу: національна свідомість і гордість, національна честь, глибокий патріотизм, національна солідарність та національна дисципліна"6 .

Відштовхуючись від означених якостей керівництво ОУН (б) мало на меті через розробку та втілення системи заходів формувати нову генерацію молоді. Ї̈̈ представники розглядалися як одна із запорук концепції опертя на власні сили, сутність якої зводилася до того, що "ми самі в першій мірі є творцями нашого буття, і від нас залежить, який шлях ми собі стелимо в майбутне"7.

Стосовно зовнішньополітичних інспірацій, спрямованих на реалізацію означеної вище національної мети у формі УССД, позиція проводу ОУН (б) представлялася ним такою, що контрастувала із визначальними формами активності вітчизняної дипломатії періоду 1917-1921 рр. У концепції “співпраці з другими народами” представниками Центрального Проводу (далі - ЦП) ОУН (б) підкреслювалося, шо “ми шукаємо пунктів

\footnotetext{
${ }^{4} 30$ червня 1941 р. Стрілеиькі вісті. Орган ВШВО ІІ. 1944 (Рік І). Ч. 19. 30 червня 1944 р. ; Літопис УПА. Нова серія / за ред.: В. Мороз, О. Вовк / НАН України, Ін-т української археографії та джерелознавства ім. М. С. Грушевського НАН України, Державний комітет архівів України, ЦДАГО України, ГДА СБУ. Київ ; Торонто : Літопис УПА, 2009. Т. 13 : Воєнна Округа УПА “Буг” 1943-1952. Документи і матеріали. Кн. II. С. 459.

${ }^{5}$ Гарасимів І., "Палій", рой. 3 юнацьких мрій - у ряди УПА (Спогади ройового УПА). Літопис УПА. Основна серія. Торонто ; Львів : Вид-во “Літопис УПА” ; Спільне українсько-канадське підприємство “Літопис УПА”, 1999. Т. 29 / під ред.: І. Тимочко-Камінської та С. Голяша. С. 21.

${ }^{6}$ Марко Боєслав. Власні сили - динаміт і цемент нації (Думки в 7-му річницю створення УПА). Неnеріодичне видання УПА “Чорний ліс”. Дрогобич ; Станіславів ; Чернівці, 1949 (Р. ІІІ.). Ч. 2 (13). Жовтень 1949 р. Літопис УПА. Основна серія / за ред.: Ю. Штендера, П. Потічний. Торонто : Літопис УПА, 1979. Т. 4 : Чорний ліс / видання команди Станиславівського тактичного відтинка УПА (Чорний Ліс). 1947-1950. Передрук підпільного журналу УПА. Кн. II: 1948-1950. С. 133.

7 “Стрийський”, “Степанович”. ШВО (III) Наказ ч. 3/45 “Командирам чот і вище” (12 липня 1945 р.). Лiтопис УПА. Нова серія / редкол.: П. Сохань, П. Й. Потічний, Г. Боряк, В. Лозицький, Р. Пиріг, Ю. Шаповал, О. Удод, С. Кокін, М. Посівнич ; НАН України, Ін-т української археографії та джерелознавства ім. М. С. Грушевського НАН України, Державний комітет архівів України, ЦДАГО України, ГДА СБУ. Київ ; Торонто : Літопис УПА. 2012. Т. 20 : Воєнна Округа УПА “Лисоня”. Документи і матеріали. 1943-1952. C. 85.
} 
спільних інтересів нашої боротьби з інтересами других народів і держав і на цій площині формуємо основи для нашої міжнародної співпраці” і “український нарід ... в своїй боротьбі проти ворожих імперіалізмів стане рам'я-об-рам'я тільки з тими народами, що визнають його право на власне самостійне державне життя"

Така позиція доповнювалася узагальненнями, що їх робилося з огляду на існуючу дійсність. Так, керівники регіонального рівня націоналістичного підпілля у післявоєнний період відзначали, що “жодні паризькі, лондонські, нью-йоркські та інші наради чи асамблеї, які до сьогодні не дали нічо позитивного, і на майбутнє нічо не дадуть"9. Цим, окрім іншого, обумовлювалася правильність згаданої вище думки про першочерговість опертя на власні сили у процесі боротьби за УССД.

Більш ширшим полем використання етосу та традицій державотворення періоду національної революції 1917-1921рр. стала царина ідеологічного характеру та сфера військового будівництва. Приклад державотворчих зусиль попередників використовувався ідеологами ОУН (б) для витворення та кристалізації окремих рис, що мали б ознаменовувати поставу оунівця-підпільника чи бійця УПА. У відповідних матеріалах наголошувалося, що “визвольні змагання 1917-1921рр. вповні підтвердили лицарську вдачу українського вояцтва, його чесноти, показали всьому народові, що слава давніх закованих у залізо воїнів, чубатих запоріжців - не загинула, а збереглась"10.

У спогадах сучасників стверджується, що етос боротьби за суверенність ставав одним із найдієвіших чинників у витворенні своєї позиції в умовах військової дійсності. Іван Гарасимів, для прикладу, коментуючи рішення стати до лав УПА стверджував, що “моїми героями були запорізькі козаки, січові стрільці, вояки армії УНР, УГА, "Карпатської Січі" ... Я вважав, що це велике щастя і гордість - бути вояком української нації”" . Схожі ремарки містяться у споминах Степана Стебельського: “... у 1918 році, мене, чотирилітнього хлопчика, піднесла мати на руках і показала на людей, що зібрались біля школи. ... Маленьким хлопцем я запам'ятав цей образ, і він залишився в пам'яті до сьогодні. Я бачу синьо-жовтий прапор, рушниці й коси. Мій батько іде 3 селянами воювати за Україну...”12.

Приклади означеної тяглості можна простежити також і у військовій сфері. У друкованих виданнях націоналістичного крила національного руху Опору вміщувалися правила статутного характеру ДА УНР ${ }^{13}$.

\footnotetext{
${ }^{8}$ Постанови III Конференції Організації Українських Націоналістів Самостійників Державників (неповний текст). Ідея і чин. 1943 (Рік. ІІ). № 3. Літопис УПА. Основна серія / за ред.: Ю. Маївського, Є. Штендери. Торонто : Літопис УПА, 1995. Т. 24 : Ідея і чин : Орган Проводу ОУН, 1942-1946. Передрук підпільного журналу. С. 138, 141.

9 Бутинський С., “Кудеяр”. Звіт за третий квартал 1948 р. (12 жовтня 1948 р., надрайон Броди). Літопис УПА. Нова серія / за ред.: М. Романюк ; НАН України, Ін-т української археографії та джерелознавства ім. М. С. Грушевського НАН України, Державний комітет архівів України, ЦДАГО України, ГДА СБУ. Київ ; Торонто : Літопис УПА, 2014. Т. 24 : Золочівська округа ОУН : Організаційні документи. 1941-1952. С. 696.

${ }^{10}$ Стрілецькі вісті. Орган ВШВО ІІ. Ч. 15-16. Рік І. 16. 6. 1944. Літопис УПА. Нова серія / НАН України, Ін-т української археографії та джерелознавства ім. М. С. Грушевського НАН України, вид-во “Літопис УПА”, Державний комітет архівів України, ЦДАГО України, ГДА СБУ. Київ ; Торонто, 2009. Т. 13 : Воєнна Округа УПА “Буг” 1943-1952. Документи і матеріали. Кн. II. С. 446.

${ }^{11}$ Гарасимів І., “Палій”, рой. 3 юнацьких мрій - у ряди УПА... С. 23.

${ }^{12}$ Стебельський С. "Хрін”. Крізь сміх заліза. Літопис УПА. Основна серія. Торонто ; Львів : Вид-во “Літопис УПА”, 2000. Т. 30 : Степан Стебельський (“Хрін”), Олекса Конопадський (“Островерх”). Крізь сміх заліза (Хроніки) / під ред. П. Й. Потічного. С. 64.

${ }^{13}$ Бойові правила армії УНР (виняте зі “Статуту Польової Служби” армії УНР з 1921 р., затвердженого Головним Отаманом С. Петлюрою). Стрілеиькі вісті : Орган ВШВО II. Ч. 6. Рік II. червень 1945 р. ; Лiтопис УПА. Нова серія / НАН України, Ін-т української археографії та джерелознавства ім. М. С. Гру-
} 
Отож боротьба за реалізацію права на національне самовизначення та державний суверенітет стала одним із визначальних проявів політичної активності української нації у XX ст. У період національної революції вона увінчалася здобуттям означеної цілі у формах УНР та ЗУНР. Існування означених національних державних організмів у силу комплексу внутрішніх та зовнішніх причин було короткотривалим.

Одначе пам'ять про цей етап національної історії та епос героїки державницьких змагань стали одними із визначальних чинників що обумовлювали подальші спроби національної спільноти осягнути втрачене. Саме тому ОУН (б), яка продовжувала боротьбу за державний суверенітет у міжвоєнний період та під час Другої світової війни досить широко використовувала героїку попереднього етапу боротьби за самостійність.

Однією із сфер застосування етосу національної революції стало виховання підростаючого покоління. У практиці роботи з молоддю представники ОУН (б) наголошували на необхідності продовжувати розпочату предками справу державотворення.

Водночас наголошувалося на необхідності плекання внутрішньої готовності до "ге-

ройського чину” заради окресленої мети. Саме у цьому випадку чи не найчастіше покликалося на осяги звитяжців періоду національної революції.

Проте праця із молодіжним середовищем не трактувалася ідеологами ОУН (б) як самоціль. Тому чи героїчний контент експлуатувався як у процесі формування політичних концепцій, а також ідеологічних підвалин збройного змагу за право реалізації національної ідеї, так і безпосередньо у справі постання та розгортання військових формацій - УПА та УНС. Саме вони на етапі 1943-1944 рр. визначалися чи не найвагомішими чинниками в осягненні загальної мети - УССД.

\title{
HEROICS OF AN NATIONAL STATE-BUILDING IN 1918-1919 AT THE FORMATION OF THE IDEOLOGICAL BASIS OF MILITARY ACTIVITY OF THE OUN (B) IN HALYCHYNA (second half of 1943 - beginning of 1944)
}

\author{
Ihor DROHOBYTSKYI \\ Ivano-Frankivsk Regional Institute of Postgraduate Teacher's Education, \\ Department of a Theory and Methods of Teaching, \\ A. Mitskiewich sq. 3, 76000, Ivano-Frankivsk, Ukraine \\ e-mail:drogobutsky@ukr.net \\ Roman ROMANIV \\ Ivano-Frankivsk National Technical University of Oil and Gas, \\ Department of Military Training, \\ Y. Konovalets st. 72 a, 76018, Ivano-Frankivsk, Ukraine \\ e-mail:1977lem1977@gmail.com
}

\begin{abstract}
The national state-making struggle in the XX century envisages a consistent deployment of the activity of a national community from the events of the national revolution of 1917-1921 in their regional dimension, the state aspirations of the interwar period and the attempts to exercise sovereignty during World War II. The article outlines the basic principles of the OUN (b) ideological platform in 1943-1944. Emphasis is on the consistency in the use of individual components of the national idea. As well some aspects of the use of the ethos of the liberation competitions of the Ukrainian military formations in 1917-1921 are presented.

The peculiarities of using of the leadership of OUN $(b)$ of the heroics of a Ukrainian Halyc'ka Army and the army of Ukrainian People's Republic for create the ideological basis of the process of deployment of the Ukrainian Armed Forces and the Ukrainian Insurgent Army are outlined.
\end{abstract}

шевського НАН України, вид-во “Літопис УПА”, Державний комітет архівів України, ЦДАГО України, ГДА СБУ. Київ ; Торонто, 2009. Т. 13 : Воєнна Округа УПА “Буг” 1943-1952. Документи і матеріали. Кн. II. С. 674-675. 
The use of the method of comparative analysis made it possible to detect the parallels in determining the ultimate goal of a nation's armed struggle. Differences in the concept and tactics of the national liberation movement are also presented

Studies of the presented topic make it possible to fully understand the process of asserting national rights, and, in particular, state independence, in the domestic society. In the current reality, the analysis of this field is actualized by the need to consolidate the national community in the struggle for the realization of the components of the national idea.

In the course of coverage of the topic, emphasis was placed on the use of published materials of the national nationalist underground and sources of memoirs.

Keywords: statehood, national sovereignty, the Resistance movement, the nationalist underground, the Organization of Ukrainian Nationalists, the Ukrainian Insurgent Army.

\section{REFERENCES}

30 chervnia 1941 r. Striletski visti. Orhan VShVO II. 1944 (Rik I). Ch. 19.30 chervnia 1944 r. Litopys UPA. Nova seriia / za red.: V. Moroz, O. Vovk / NAN Ukrainy, In-t ukrainskoi arkheohrafii ta dzhereloznavstva im. M. S. Hrushevskoho NAN Ukrainy, Derzhavnyi komitet arkhiviv Ukrainy, TsDAHO Ukrainy, HDA SBU. Kyiv ; Toronto : Litopys UPA, 2009. T. 13 : Voienna Okruha UPA "Buh" 1943-1952. Dokumenty i materialy. Kn. II. S. 459. [in Ukrainian].

Boiovi pravyla armii UNR (vyniate zi "Statutu Polovoi Sluzhby" armii UNR z 1921 r., zatverdzhenoho Holovnym Otamanom S. Petliuroiu). Striletski visti : Orhan VShVO II. Ch. 6. Rik II. cherven 1945 r. ; Litopys UPA. Nova seriia / NAN Ukrainy, In-t ukrainskoi arkheohrafii ta dzhereloznavstva im. M. S. Hrushevskoho NAN Ukrainy Derzhavnyi komitet arkhiviv Ukrainy, TsDAHO Ukrainy, HDA SBU. Kyiv ; Toronto : Litopys UPA, 2009. T. 13 : Voienna Okruha UPA "Buh" 1943-1952. Dokumenty i materialy. Kn. II. S. 674-675. [in Ukrainian].

Butynskyi S., “Kudeiar”. Zvit za tretyi kvartal 1948 r. (12 zhovtnia 1948 r., nadraion Brody). Litopys UPA. Nova seriia / za red.: M. Romaniuk ; NAN Ukrainy, In-t ukrainskoi arkheohrafii ta dzhereloznavstva im. M. S. Hrushevskoho NAN Ukrainy, Derzhavnyi komitet arkhiviv Ukrainy, TsDAHO Ukrainy, HDA SBU. Kyiv ; Toronto : Litopys UPA, 2014. T. 24 : Zolochivska okruha OUN : Orhanizatsiini dokumenty. 1941-1952. S. 696. [in Ukrainian].

Harasymiv I., "Palii", roi. Z yunatskykh mrii - u riady UPA (Spohady roiovoho UPA). Litopys UPA. Osnovna seriia. Toronto ; Lviv : Vyd-vo "Litopys UPA"; Spilne ukrainsko-kanadske pidpryiemstvo "Litopys UPA", 1999. T. 29 / pid red.: I. Tymochko-Kaminskoi ta S. Goliasha. S. 21. 23. [in Ukrainian].

Ukrainian].

Istoriia ukrainskoho viiska. 1917-1995 / upor.: Ya. Dashkevych. Lviv : Svit, 1996. 840 s. [in

Kyrychuk Yu. Narysy z istorii ukrainskoho natsionalno-vyzvolnoho rukhu 40-50-kh rokiv XX st. Lviv : Lvivskyi nats. un-t im. Ivana Franka, 2000. 305 s. [in Ukrainian].

Kyrychuk Yu. Ukrainskyi natsionalnyi rukh 40-50-kh rokiv XX stolittia : ideolohiia i praktyka. Lviv : Lvivskyi nats. un-t im. I. Franka. Dobra sprava. 2003. 463 s. [in Ukrainian].

Marko Boieslav. Vlasni syly - dynamit i tsement natsii (Dumky v 7-mu richnytsiu stvorennia UPA). Neperiodychne vydannia UPA "Chornyi lis". Drohobych ; Stanislaviv ; Chernivtsi, 1949 (R. III.). Ch. 2 (13). Zhovten 1949 r. Litopys UPA. Osnovna seriia / za red.: Yu. Shtendera, P. Potichnyi. Toronto : Litopys UPA, 1979. T. 4 : Chornyi lis / vydannia komandy Stanyslavivskoho taktychnoho vidtynka UPA (Chornyi Lis). 19471950. Peredruk pidpilnoho zhurnalu UPA. Kn. II : 1948-1950. S. 133. [in Ukrainian].

Postanovy III Konferentsii Orhanizatsii Ukrainskykh Natsionalistiv Samostiinykiv Derzhavnykiv (nepovnyi tekst). Ideia i chyn. 1943 (Rik. II). № 3. Litopys UPA. Osnovna seriia / za red.: Yu. Maivskoho, Ye. Shtendery. Toronto : Litopys UPA, 1995. T. 24 : Ideia i chyn: Orhan Provodu OUN, 1942-1946. Peredruk pidpilnoho zhurnalu. S. 138, 141. [in Ukrainian].

Postanovy III Nadzvychainoho Velykoho Zboru Orhanizatsii Ukrainskykh Natsionalistiv, shcho vidbuvsia v dniakh 21-25 serpnia 1943 r. Ideia i chyn. 1943 (Rik II). № 5. Litopys UPA. Osnovna seriia / za red.: Yu. Maivskoho, Ye. Shtendery. Toronto : Litopys UPA, 1995. T. 24 : Ideia i chyn: Orhan Provodu OUN, 1942-1946. Peredruk pidpilnoho zhurnalu. S. 231. [in Ukrainian].

"Ratai". Za derzhavu. Striletski visti. Orhan VShVO II. 1944 (Rik I). Ch. 19. 30 chervnia 1944 r. Litopys UPA. Nova seriia / redkol.: / NAN Ukrainy, In-t ukrainskoi arkheohrafii ta dzhereloznavstva im. M. S. Hrushevskoho NAN Ukrainy, Derzhavnyi komitet arkhiviv Ukrainy, TsDAHO Ukrainy, HDA SBU. Kyiv ; Toronto : Litopys UPA, 2009. T. 13 : Voienna Okruha UPA "Buh" 1943-1952. Dokumenty i materialy. Kn. II. S. 455. [in Ukrainian]. 
Stebelskyi S., "Khrin". Kriz smikh zaliza. Litopys UPA. Osnovna seriia. Toronto ; Lviv : Vyd-vo "Litopys UPA", 2000. T. 30 : Stepan Stebelskyi ("Khrin”), Oleksa Konopadskyi (“Ostroverkh"). Kriz smikh zaliza (Khroniky) / pid red. P. Y. Potichnoho. S. 64. [in Ukrainian].

Striletski visti. Orhan VShVO II. Ch. 15-16. Rik I. 16. 6. 1944. Litopys UPA. Nova seriia / NAN Ukrainy, In-t ukrainskoi arkheohrafii ta dzhereloznavstva im. M. S. Hrushevskoho NAN Ukrainy, Derzhavnyi komitet arkhiviv Ukrainy, TsDAHO Ukrainy, HDA SBU. Kyiv ; Toronto : Litopys UPA, 2009. T. 13 : Voienna Okruha UPA "Buh" 1943-1952. Dokumenty i materialy. Kn. II. S. 446. [in Ukrainian].

"Stryiskyi", "Stepanovych". ShVO (III) Nakaz ch. 3/45 "Komandyram chot i vyshche" (12 lypnia 1945 r.). Litopys UPA. Nova seriia / redkol.: P. Sokhan, P. Y. Potichnyi, H. Boriak, V. Lozytskyi, R. Pyrih, Yu. Shapoval, O. Udod, S. Kokin, M. Posivnych ; NAN Ukrainy, In-t ukrainskoi arkheohrafii ta dzhereloznavstva im. M. S. Hrushevskoho NAN Ukrainy, Derzhavnyi komitet arkhiviv Ukrainy, TsDAHO Ukrainy, HDA SBU. Kyiv ; Toronto : Litopys UPA. 2012. T. 20 : Voienna Okruha UPA "Lysonia". Dokumenty i materialy. 19431952. S. 85. [in Ukrainian].

Zbirnyk materialiv I Mizhnar. nauk. konf. "Natsionalno-vyzvolna borotba 20-50-kh rokiv XX st. v Ukraini”. Kyiv ; Lviv, 1993. 293 s. [in Ukrainian]. 